\title{
EARTHQUAKE ENGINEERING RESEARCH AND DEVELOPMENT CURRENT NEEDS
}

\author{
EDITOR'S NOTE:
}

The time is ripe for a review of directions in which earthquake engineering research is, or should be, heading. Half a century has elapsed since New Zealand suffered a serious earthquake in an urban area - during that time, immense changes have developed in both the form and complexity of structures and services. Researchers are tending to think more and more about less and less in their respective encapsulated environments. Are we getting to the stage where aspects of the problem are being well researched but their interdependence is being lost sight of? Or are we even missing important wider aspects? A need encompassing all topics is the matter of keeping abreast of developments being done elsewhere.

In this issue, we commence a series of general articles. These are intended primarily as a stimulus for comment.

\section{BUILDINGS: RESEARCH AND DEVELOPMENT NEEDS}

\author{
D.L. Hutchison*
}

\section{STRUCTURE}

1. THE TREND TO ÓFFSITE MANUFACTURE:

Economics is dictating an increase in offsite manufacture of structural building components. Precast concrete panel construction of walls as well as slabs are in growing evidence as is precut timber for buildings.

This situation places a new emphasis on the need for adequate connections between structural elements. Whereas with insitu reinforced concrete construction walls were "automatically" tied to the slab, such connection must be specifically sought in the design stages when prefabricated elements are used. Not only is the strength of connectors important, but any tendency for them to work loose may lead to excessive deflection, reduced energy dissipation, and greater acceleration response under seismic loading.

Associated with the trend to offsite manufacture of building components is a mixing of material types - structural steel bracing in the horizontal plane with precast concrete walls, plywood floors with concrete walls, for example. Some of these combinations consist of components of widely different stiffness properties. The distribution of seismic forces between members may be radically different from the usual case of an "infinitely stiff" diaphragm.

Timber is a lightweight building material. Modifications of the fire rating requirements now allow for multistorey construction. These factors together with the demand to use indigenous materials and innovative technology, these have brought about upsurge in use of structural timbers. New technologies and changes in material stocks through advanced silviculture require a constant re-assessment and testing to provide

* Ministry of Works and Development, Wellington.

BULLETIN OF THE NEW ZEALAND NATIONAL SOCIETY FOR EARTHOUAKE ENGINEERING, VOL. 15, NO. 2, JUNE 1982 designers with appropriate values.

Structural steel has always been regarded as a most satisfactory performer for ductility. Lateral supports to prevent buckling are common $\frac{1}{r} y$ required at $960^{\mathrm{r}} \mathrm{y}$ or even only $640^{\mathrm{r}} \mathrm{y}$. Some recent tests on another investigation* gave significant flange and web buckling at $\mathrm{DF}=2$, and at apparently well within the lateral support limits. With the number of structural steel structures built and proposed there is an urgent need to follow this anomaly to an end to ensure the safety of structures.

The Need:

- Cyclic static or dynamic load testing of prefabricated sub-assemblages.

\section{STRENGTHENING OF OLD BUILDINGS:}

In very recent times, the upgrading of old buildings to better resist earthquake and even to achieve compliance with the current Loadings code has become more a feature of a city's construction activity. Frequently, a reinforced concrete shear wall structure is achieved by application of sprayed concrete to reinforcing mesh tied adjacent to inner faces of existing brick walls. Existing timber floors may be used as permanent formwork to support a cast-insitu reinforced concrete overlay. Economically appealing is the use of vertical post-tensioning to improve the shear strength of brick walls. However, it is possible that, particularly in the case of brickwork of low cement content in the mortar, the benefits of prestress could be quickly eroded by creep. Other solutions for strengthening the walls involve a thin lamina applied to both sides, for example Glass Reinforced Cement. Steel Fibre Reinforced Concrete, glued steel sheet. 
The relative economics and performance of these solutions are not yet known. How do we treat the connection of veneer to structural brick? Installation of new ties is one possibility. Grouting of the cavity (if it exists) at the veneer may achieve sufficient bond but give rise to efflorescence - small comfort to the owner if "the building looked much better before it was strengthened". Or should we accept that the veneer can fall off, and concentrate instead on preventing building collapse? The answer no doubt depends on the particular situation but it is clear that criteria are lacking at present.

"Strengthening" may be required by the client merely to enable the building to be used for a finite additional

time, for which a reduced seismic strength is appropriate. In this situation, a definitive method of calculating reduced loading is lacking.

The Needs:

- Laboratory testing of possible strengthening solutions with indication of relative costs.

- Guidelines regarding treatment of nonstructure, such as veneers.

- Guidelines for calculating loadings when a reduced period of service is being sought.

\section{ENERGY ABSORBING DEVICES:}

These devices, of various types, have come into use in recent years in the case of a variety of bridges around the country and in two buildings to date. Attention is being currently directed also towards taking advantage of the lower design loads made possible by such devices in the case of more prefabricated forms of construction such as braced steel frames. clearly there will be a lower limit to the size of building (number of storeys) which can benefit from these devices because the product of applied load and plastic deformation - is the energy absorbed - must be sufficiently large.

The Need:

- Further analytical, experimental and economic study to determine feasible uses of energy absorbing devices.

\section{NON-STRUCTURE}

\section{BUILDING SERVICES:}

The imminent publication of NZS 4219 "Seismic Resistance of Engineering Systems in Buildings" will serve to focus attention on a problem that is not yet appreciated by all practitioners of building services design. The cost of building services in a moderate height building may reach $35 \%$ of the total cost, and hence as a significant economic component, in their own right, building services require adequate protection. Further, the effect of failure of as insignificant a component as a sewer line can temporarily prevent occupancy of an entire building, and hence has significant economic consequences.

The Need:

- To publicise the place of seismic considerations in the basic design of building services components.

\section{ARCHITECTURAL}

There remains the continuing need to foster recognition that the most innocuous and "clearly non-structural" components may have dramatic effects on a building subjected to seismic attack eccentric masonry infill panels and an eccentric nest of full-height partitions to name but two.

The subject of separations is a source of tension between architect and structural engineer and the need to satisfy fire protection and accoustic requirements across the separation may lead to compressible fillers demonstrating that their ability to transmit loads across the "gap" should not have been ignored by the designs. It is likely that a future relatively modest earthquake will result in a bill for non-structural repairs which is tens of times greater than that for repairs to the structure. Much of this will be due to a lack of attention to detailing of separations.

The Need:

- to publicise the need for, and examples of, workable separation details.

\section{CURRENT AND PLANNED EARTHQUAKE ENGINEERING}

\section{RESEARCH IN MINISTRY OF WORKS AND DEVELOP-} MENT STRUCTURAL SECTION

1. Testing of Strengthened Brickwork:

Cyclic load testing in shear brick wall panels is currently being carried out at Central Laboratories. The series, expected to be completed in mid-1982, involves consideration of the following potential strengthening methods:

- vertical prestress

- sprayed concrete reinforced, to one face

- glass reinforced cement, plaster coat to both faces

- steel fibre reinforced cement, to both faces

- steel fibre reinforced cement, to both faces

- ferrocement coating to both faces

Wall panels $(2.400$ high $\times 1.600$ long) are being constructed out of new bricks; however, in the case of the prestressed wall units, solid bricks have been obtained and a mortar used which approximates a mix current before the $1930 \mathrm{~s}$. 
2. Testing of Mechanical Splices for Reinforcement:

A new series of both static and dynamic testing is underway using high yield $40 \mathrm{~mm}$ and $20 \mathrm{~mm}$ bars and three available splicing systems, namely cadweld, CCL, and NMB.

3. Development and Testing of BeamColumn Joints for Different Beam Materials:

One and two-storey buildings of reinforced concrete columns may support floor or roofing systems on timber or steel beams. In this project, feasible connector designs will be considered and then tested in order to ascertain their competence in resisting cyclic lateral loading.

\section{Torsional Response of Buildings:}

By means of three-dimensional. elasto-plastic dynamic analyses on a variety of buildings more insight is being sought regarding the amplification of torsional seismic input.

5. Assessment of the Performance of Rivetted Connections:

Preliminary tests have been carried out on $22 \mathrm{~mm}(7 / 8$ in) rivets in tension and in shear. These will be followed later in the year by laboratory testing of a full size beam/column concrete encased assemblage after an existing building constructed in the 1930s.

\section{Optimum Shear-Walls:}

This theoretical study, now underway, is investigating ways of altering the form of shear walls so as to optimise strength and stiffness and improve the building economics.

\section{Reinforced Hollow Masonry:}

Towards the end of this year, it is planned to test some masonry spandrel beams in reversed curvature. This may lead on to tests of RHM beam-column sub-assemblages.

\section{Testing of Timber Fasteners:}

Several types of timber fasteners are being tested under cyclic load conditions in order to determine better the stress for seismic design of joints, both parallel and perpendicular to the grain.

9. Properties of Existing Brickwork:

Panels in one old building have been tested. Additional equipment is to be fabricated before proceeding to other structures.

\section{Seismic Energy Absorption:}

Equipment for testing brake pad and yielding rod systems are being fabricated. 